\title{
AKUNTANSI KEHAKIMAN
}

\author{
Burhanudin Gesi ${ }^{1)}$ \\ ${ }^{1)}$ Dosen Tetap Program Studi Manajemen Universitas Muhammadiyah Kupang
}

\begin{abstract}
ABSTRAKSI
Ranah hukum membutuhkan kepastian, keadilan, dan kemanfaatan masyarakat. Demi keadilan yang ber-KeTuhanan, hukum mesti ditegakan dalam segala aspek kehidupan manusia. Hukum bukanlah suatu skema yang final, namun terus bergerak, berubah, mengikuti dinamika kehidupan manusia. Karena itu, hukum tetap terus dibedah dan digali melalui usaha-usaha nyata untuk mencapai terang cahaya kebenaran dalam menggapai keadilan. Manusia selaku aktor terpenting dan utama dibelakang kehidupan hukum tidak hanya dituntut untuk mampu menciptakan dan menjalankan hukum (making the law), tetapi juga keberanian untuk mematahkan dan merobohkannya (breaking the law) manakala hukum tidak sanggup menghadirkan roh dan substansi keberadaannya, yakni mampu menciptakan keharmonisan, kedamaian, ketertiban, dan kesejahteraan masyarakatnya. Dalam proses penegakan hukum, agar tidak mencederai rasa keadilan masyarakat, mengikuti prosedur dan mekanisme yuridis semata, menerapkan pasal-pasal dan bunyi undang-undang saja, melainkan proses yang melibatkan perilaku-perilaku masyarakat yang berlangsung dalam struktur sosial tertentu. Misalnya saja, seorang hakim tidak boleh menolak suatu perkara yang diajukan kepadanya dengan alasan tidak ada hukum yang mengatur berkenaan dengan obyek perkara yang diajukan, atau hakim tidak mengetahui hukumnya. Hakim dalam memutuskan suatu perkara harus bisa menemukan hukumnya (rechtvinding) dan membentuk hukum baru (rechtvorming) jika perkara yang diajukan kepadanya belum ada hukum tertulis yang mengaturnya, karena hukum tidak saja bersifat tatanan aturan secara tekstual an sich (ordegenik) tetapi juga dalam tatanan kontekstual berbasis fleksibel. Dengan demikian sebuah peristiwa hukum, ketika diajukan dalam proses peradilan, hakim membutuhkan dokumen transaksi (bukti-bukti dan alat bukti) yang cukup, dan dapat dijadikan sebagai dasar pertimbangan dalam memeriksa, memutus, dan mengadili sebuah perkara. Dan disanalah peran besar seorang ahli akuntansi keuangan (AAK).
\end{abstract}

Kata Kunci: Akuntansi Kehakiman, Ahli Akuntansi Keuangan, Keterangan Ahli Akuntansi

\section{A. PENDAhuluan}

Penasehat hukum kemudian menyatakan bahwa justru kami tahunya setelah proses ini berlangsung di muka sidang, pak. Jadi dari proses di muka sidang kami melihat misalnya pernyataan dari pengurus koperasi "KUD Ledomata" yang beralamat di jalan bajawa No 29- Oepoi Kupang NTT tersebut, yang telah diperlihatkan di muka sidang, ditandatangani oleh Ketua, Sekretaris dan Bendahara, disana disebutkan bahwa khusus pada Divisi pemasaran terdapat piutang sebesar Rp 17.290.237,05,- yang telah jelas dukungan pembuktianya sebesar Rp 6.115.258,- dan sisanya sebesar Rp 11.174.979,05,dukungan pembuktianya akan ditelusuri kemudian, lalu didalam laporan yang dibuat pengurus seperti yang termuat didalam laporan badan pengawas sendiri, itu kami membaca adanya kekayaan KUD Ledomata yang masih harus dipertangung jawabkan oleh devisi pemasaran sebesar Rp 7 juta lebih per 31 desember 2010, lalu per 4 agustus 2015 menjadi Rp 7. 331.069,13 lalu kami juga menjumpai angka lain, yaitu dari hasil pemeriksaan akuntan publik Yusuf yang isinya berbunyi dari mulai KUD Ledomata 
berdiri itu, kekayaanya yang masih harus dipertanggung jawabkan sebesar saya Interupsi sebentar, kata Hakim Ketua.......

Cuplikan di atas merupakan ungkapan dalam sidang masalah KUD Ledomata di Pengadilan Negeri Klas 1 A Kupang pada 17 Nopember 2015. Dari data ini terungkap adanya sejumlah dana yang dipermasalahkan dengan versi yang berbeda. Jadi berapa sebenarnya jumlah dana yang dipermasalahkan dalam perkara ini ? Kalau dilihat lebih jauh, maka perkara ini timbul akibat dari adanya suatu bisnis, dimana merupakan suatu kegiatan ekonomi. Dalam kehidupan ekonomi ini, banyak perhitungan yang harus dilakukan misalnya tentang berapa biaya, berapa penghasilan dan seterusnya. Salah satu alat hitung dalam kehidupan ekonomi ini adalah apa yang dinamakan "akuntansi".

Bila tindak pidana semacam
W hite Collar Crime (W CC),
atau kejahatan kera putih
sampai ditangan pengadilan,
biasanya akan timbul masalah
yang kompleks terutama dalam
bidang keuangan

\section{B. KONSEP AKUNTANSI KEHAKIMAN}

Secara teoritikal, tidak banyak ahli ataupun pakar yang memberikan defenisi/batasan secara pasti mengenai akuntansi kehakiman. Namun, tulisan ini ingin memberikan referensi tentang hubungan hukum dalam menerapkan kepastian dan keadilan di mata masyarakat, khususnya yang berkaitan dalam aspek penggunaan/pengelolaan keuangan negara da daerah. Menurut Bawazir Fuad, 2015, dalam "Visi Keuangan Negara yang Akuntable" mengintrodusir, dalam teori pengelolaan anggaran yang akuntable tersusunlah logika keuangan yang terbuka dan bertanggung jawab dan diperlukan oleh staeckholders dan pemangku kepentingan. Lebih lanjut menurut Bawazir Fuad, yang dimaksud dengan "staeckholders dan pemangku kepentingan" adalah penguasa, pengusaha, dan dunia usaha. Ketiga kelompok dan atau elemen tersebut dinilai sangat elitis dalam menggunakan bukti-bukti pengeluaran sebagai peruntukan pos-pos/item-item kegiatan dalam rangka kepentingan pengawasan. Sementara itu, Brotohadihardjo R. Santoso, 2016 "Tax Law Of Science Accounting Benefit" mengemukakan bahwa, negara (pemerintah) khususnya para pembuat keputusan berbasis anggaran yang tidak merugikan negara, membutuhkan penetapan pajak dalam segala jenis sesuai tingkat akurasi jumlah nominal yang telah ditentukan. Sedangkan menurut : Majalah Ternama, 2016, “Peradilan MA Warta Pengawasan” mengutip pendapat Bagir Manan Mantan Ketua MA RI : ruang peradilan tetap memerlukan dukungan bukti-bukti keuangan sebagai pembedah, celah, relativisasi law aproof untuk membangun, dan menentukan obyek sebuah perkara yang terang benderang. Biarlah hakim dengan kebebasannya dan otoritasnya yang digunakan demi memeriksa, mengadili dan memutuskan perkara bersalah tidak bersalah seseorang. Para aparat penegak hukum sangat memerlukan/membutuhkan bukti dan atau alat bukti yang dapat disesuaikan keterangan ahli (keuangan) di muka persidangan. Menyajikan data dan informasi yang 
akurat sehubungan dengan desain/perencanaan pengelolaan keuangan negara dan atau daerah. Polisi, jaksa, dan hakim didalam melaksanakan tugasnya membutuhkan bukti pendukung sebagai dasar penyelidikan dan penyidikan. Keterangan ahli akuntansi dapat membuka tabir tentang rahasia bagi para pemangku kepentingan mengelola dana/anggaran yang berbasis kinerja yang didasarkan kepada DIPA dari satker masingmasingnya. Terlebih lagi didepan para majelis hakim yang seyogianya dapat menguraikan dan menggambarkan seluruh tahapan dan proses pengumpulan dokumen transaksi. Uraian ataupun gambaran sedetail apapun tentang bukti-bukti transaksi dapatlah disesuaikan dengan keterangan ahli yang berkecimpung dibidangnya. Dialah yang dapat menguasai, berdasarkan kualifikasi keilmuan yang telah dimiliki. Keterangan dimaksud, bahwa untuk memberikan keyakinan kepada hakim dalam fakta persediangan tentang benar tidak duduknya sebuah perkara. Dengan demikian maka dapat disimpulkan bahwa = konteks memberikan keterangan dalam ruang peradilan seyogianyalah "ahli". Ahli yang dimaksudkan adalah seseorang yang memiliki kualifikasi bidang ilmu tertentu, khususnya dalam bidang keuangan yang dapat dengan keahliannya memberikan informasi yang berguna, dan berkaitan dengan konteks yang dibutuhkan oleh hakim. Karena sebelumnya yang bersangkutan telah diambil sumpah dan atau janji, agar yang bersangkutan dapat memberikan keterangan/informasi yang benar, akurat, berdasarkan kualifikasi bidang ilmu yang telah dimilikinya. Itulah yang disebut "Keterangan Ahli Akuntansi” (KAA).

\section{PERLUKAH AKUNTANSI KEHAKIMAN ???}

Sebagai alat hitung dalam ekonomi, akuntansi pada mulanya mendapat arti dengan tekanan sebagai suatu system pencatatan dan interpretasinya. Sekarang akuntansi ini lebih dipandang aktivitas jasa yang berfungsi untuk menyediakan informasi (terutama keuangan) sebagai bahan pertimbangan dalam pengambilan keputusan.

Dengan mengikuti pola pikir yang begitu banyak variasi pengambilan keputusan, maka akuntansi mencoba untuk memasuki lingkup perilaku dan penyesuaian terhadap lingkungan pemakai informasi. Informasi akan bermanfaat, apabila informasi tersebut berguna bagi pengambilan keputusan.

Informasi akuntansi di peradilan pidana akan lebih banyak dibutuhkan sekarang, karena tindak pidana mudah lebih terorganisasi dan lebih sistematis. Saat ini orang "merampok" uang miliyaran bahkan triliunan rupiah dengan "cara halus " tidak dengan cara kasar atau dengan cara kekerasan yang mencolok (konvensional). Bila tindak pidana semacam tadi yang sekarang banyak disebut sebagai "white collar crime (wcc)" kejahatan kera putih sampai ditangan pengadilan, biasanya akan timbul masalah yang kompleks terutama dalam bidang keuangan. Akan banyak masalah keuangan yang tidak terang karena system akuntansinya serta pencatatan yang kurang jelas dan terarah.

Atas tindakan pidana apapun, bila telah sampai dimeja hijauhkan (pengadilan), maka harus diberi keputusan. Sebelum keputusan diambil harus ada kepastian tentang bukti-bukti tindak pidana tersebut. Dalam pembuktian tersebut dapat diminta bantuan ahli, dalam kasus ini, ahli akuntansi. Ahli akuntansi ini, ahli akuntansi ini akan membuat terang hal yang belum terang di pengadilan, dari sudut pandang akuntansi. Akuntansi terapan beginilah yang dikategorikan sebagai "Akuntansi Kehakiman". 


\section{KETERANGAN AHLI AKUNTANSI}

Seperti tercantum dalam KUHAP pasal 184 (1) keterangan ahli merupakan alat bukti yang sah, disamping alat bukti yang sah lainnya, seperti keterangan saksi, surat, dokumen elektronik, petunjuk, dan keterangan terdakwa. Dalam KUHAP pasal 1 (28), maka keterangan ahli adalah keterangan yang diberikan oleh seorang yang memiliki keahlian khusus tentang hal yang diperlukan untuk membuat terang perkara pidana guna kepentingan pemeriksaan.

Keterangan Ahli Akuntansi (selanjutnya dituliskan KAA) akan berisi keterangan dan penjelasan tentang keadaan suatu peristiwa maupun penilaian mengenai hal-hal yang terkait dengan akuntansi, yang pada akhirnya akan memberikan informasi akuntansi yang jelas dan relevan bagi yang berperkara.

Sesuai dengan sifat umum informasi, maka informasi akuntansi tidak boleh berisikan informasi yang memihak kepada salah satu yang berperkara. Informasi akuntansi harus diberikan apa adanya, sesuai dengan gambaran keadaan yang sebenarnya.

Hal ini akan menyulitkan bagi ahli akuntansi untuk memberikan KAA, bilamana seorang tersangka atau terdakwa yang memintahnya. Lihat KUHAP pasal 65 yang menyatakan : "Tersangka atau terdakwa berhak untuk mengusahkan dan mengajukan saksi dan atau seseorang yang memiliki keahlian khusus guna memberikan keterangan yang menguntungkan bagi dirinya." Jelas sekali apa yang disebutkan pasal tersebut, yakni pemegang keahlian ini berguna untuk memberikan keterangan yang menguntungkan bagi diri tersangka atau terdakwa.

Timbul pertanyaan, kalaulah dalam hal ini dibuatkan KAA, apakah KAA ini netral, tidak berpihak kepada yang berperkara ???? KAA semacam ini dapat disebut alat bukti yang sah dalam kategori "surat" sebagaimana tercantum dalam pasal 187c KUHAP. Permasalahan akan timbul, bila ternyata diajukan lebih dari seorang ahli untuk hal yang sama guna memberikan keterangan dimuka sidang. Apakah KAA ini akan menyulitkan persidangan pengadilan ???

Sebagai pertimbangan, ada baiknya mengkaji cuplikan berikut di depan :

"Kemudian Hakim Ketua menjelaskan kembali, saya tidak berdebat ya pak tetapi kita harus bertolak dari pada pendirian bahwa segala atau sesuatunya itu sampai terjadinya perkara ini telah dilimpahkan oleh saksi ahli dari KUD Ledomata ke kejaksaan dan badan pengawas itu, juga saksi ahli untuk menerangkan ini semua sampai terjadinya perkara ini dan kalau itu mau diadakan kenapa tanpa diajukan pada waktu pemeriksaan permulaan di kejaksaan sana.

Penasehat hukum, justru itu baru kami temukan dari proses selama dalam persidangan.

Hakim Ketua kemudian melanjutkan lagi penjelasan, sebab nanti akan terjadi dua pendapat ahli, yang satu pendapatnya sudah diajukan ke kejaksaan nanti kita kesana muaranya, kalau itu benar pendapat ahli yang saudara maksud. Pada hal saksi ahli dari badan pengawas ini setelah mengklirkan keadaan, mengajukan ke kejaksaan untuk diusut lebih jauh sampai ke persidangan, begitu pak. Nanti muaranya menjadi dua. Silahkan kalau bapak punya penemuan itu ajukanlah ke kejaksaan andaikata ketemu kebenarankebenaran menurut saksi yang demikian itu." 


\section{E. SIAPAKAH AHLI AKUNTANSI ???}

Kembali melihat kepada cuplikan berita acara sidang terdahulu maka siapa yang dapat membuat terang angka-angka tersebut guna kepentingan pemeriksaan??? Jawabannya ialah siapa saja yang mempunyai keahlian akuntansi. Apakah ini cukup dapat diwakili oleh peñata buku (book-keeper) yang sudah berpengalaman, ataukah oleh akuntan pendidik, akuntan intern, akuntan publik atau ahli akuntansi lain ?? KUHAP tidak mengatur mengenai kriteria orang yang memiliki keahlian khusus ini. Sebagai patokan dapatlah dipakai misalnya pandangan yang dijumpai pada "California Evidence Code” yang menyatakan: " Seseorang dapat memberi keterangan sebagai ahli jika ia mempunyai pengetahuan, keahlian, pengalaman, latihan atau pendidikan khusus yang memadai untuk memenuhi syarat sebagai seorang ahli tentang hal yang berkaitan dengan keterangannya."

Melihat kriteria tersebut, kiranya tidaklah berlebihan apabila yang disebutkan sebagai seorang ahli akuntansi dalam versi KUHAP ialah : akuntan yang memiliki profesi akuntan publik. Perlu diketahui, untuk dapat berpraktik sebagai akuntan publik, akuntan tersebut harus memiliki pendidikan dan pengalaman praktik dalam bidang pemeriksaan akuntan (auditing) dan bertindak independen. Selanjutnya sebut saja sebagai Akuntan Kehakiman.

\section{F. AKUNTAN KEHAKIMAN}

Akuntan kehakiman merupakan yang menjalankan fungsi akuntansi kehakiman. Akuntan ini harus bertindak obyektif dan independen. Akuntan ini seorang professional, berpengalaman dan memiliki pengetahuan yang cukup dalam mengenai Hukum Pidana. Banyak lagi yang harus dimiliki oleh akuntan kehakiman ini. Beberapa kecakapan utama yang menunjang profesi akuntansi kehakiman adalah :

Pertama, kemampuan untuk menentukan masalah yang tepat. Dalam hal ini akuntan kehakiman harus dapat mengindentifikasikan mana masalah yang relevan, mana yang bukan masalah. Kesalahan dalam menentukan permasalahan, akan membawa perkara bisa jadi tambah tidak jelas.

Kedua, kemampuan untuk menafsirkan informasi akuntansi. Satu peristiwa dapat menimbulkan bermacam tafsiran. Hendaknya setiap peristiwa harus dilihat seluruh aspeknya. Suatu tafsiran yang memadai akan diperoleh, bilamana melihat suatu peristiwa dengan penghayatan yang mendalam dan tak ada yang membatasinya.

Ketiga, kecakapan tentang teknik investigasi. Bila masalah telah ditemukan, maka perlu dilanjutkan dengan pencarian bermacam dokumen. Kemudian dilakukan penyelidikan penyidikan akuntansi dengan teknik-teknik tertentu.

Keempat, pengetahuan tentang bukti pembuktian. Harus mengetahui bukti yang relevan bagi akuntasi dan menurut hukum pidana. Tentang bukti akan dibahas lebih lanjut.

Kelima, kecakapan mengungkapkan temuan. Untuk ini dituntut kemampuan berkomunikasi dengan baik, agar temuan yang diungkapkan dapat ditanggapi oleh pemakai dengan persepsi yang sama. Ungkapan temuan itu dapat dikemukakan baik lisan, tulisan maupun dengan alat peraga lainnya. 


\section{G. PENGEMBANGAN BUKTI DALAM AKUNTANSI KEHAKIMAN}

Di dalam akuntansi, yang dapat dimasalahkan sebagai bahan bukti ialah data akuntansi beserta semua informasi penguatnya. Informasi penguat ini diperoleh akuntan kehakiman melalui : Inspeksi; Pemeriksaan Fisik; Akurasi Mekanis; Konfirmasi; Prosedur Analitis; dan Dokumentasi. Agar memenuhi syarat sebagai bukti yang kompeten, maka bukti-bukti itu harus sah dan relevan, sebagai dasar yang memadai dalam merumuskan temuannya.

Pada umumnya bagi akuntan akan lebih mengandalkan kepada bukti yang bersifat menimbulkan daripada bukti yang bersifat meyakinkan. Dari bahan bukti yang ada akuntan kehakiman cukup mencari hasil dengan tingkat keyakinan yang tinggi, tidak mencari benar $100 \%$, karena hal ini tidak mungkin.

Dengan menggunakan bahan bukti tersebut, akuntan kehakiman akan memberi kebenaran dari peristiwa dalam perkara baik secara formal maupun secara materiil.

Hukum Acara Pidana Indonesia menganut bukan saja azas formil akan tetapi juga azas materiil, seperti dapat dibaca pada pedoman pelaksanaan KUHAP yang dikeluarkan menteri kehakiman seperti berikut : "Tujuan dari hukum acara pidana adalah untuk mencari dan mendapatkan atau setidak-tidaknya mendekati kebenaran materiil, ialah kebenaran yang selengkap-lengakpnya dari suatu peritiwa pidana dengan menerapkan ketentuan hukum acara pidana secara jujur dan tepat dengan tujuan untuk mencari siapakah pelaku yang dapat didakwakan melakukan sesuatu pelanggaran hukum, dan selanjutnya meminta pemeriksaan dan putusan dari pengadilan guna menemukan apakah terbukti bahwa suatu tindakan pidana telah dilakukan dan apakah orang yang didakwakan itu dapat dipersalahkan. Dengan adanya kesamaan tujuan mencari kebanaran materiil, meskipun jalannya berbeda karena memiliki disiplin ilmu yang berbeda, maka eksistensi akuntansi kehakiman dapat diterima.

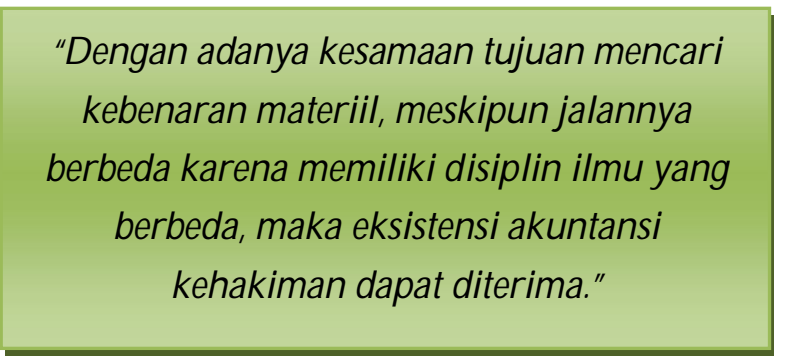

\section{H. PROSPEK AKUNTAN KEHAKIMAN}

Di Indonesia, dunia usahanya makin maju. Akuntansi, yang menjadi salah satu alat manajemen maupun sebagai alat hitung, akan maju seiring dengan kamajuan usaha. Namun kemajuan yang positif ini, akan memacu pula kemajuan dalam bidang tindak pidana. Kriminalitas dalam bidang usaha akan kian meningkat, karena adanya keinginankeinginan yang berlebihan dari para palakunya. White Collar Crime akan meningkat pula. Dan semua tindakan kriminal ini dilakukan dalam organisasi usaha.

Dengan adanya kriminalitas dalam dunia usaha, maka ini biasanya berarti terdapat ketidak beresan dalam akuntansinya, sehingga dalam sidang pengadilan, proses penentuan salah-tidaknya menjadi kompleks. Ketidak beresan akuntansi akan dapat 
diterangkan kepada semua pihak yang berperkara oleh akuntan kehakiman. Akuntan kehakiman akan bekerja secara obyektif dan independen.

Dengan adanya sikap yang demikian dari akuntan kehakiman, diharapkan semua pihak dapat menerima penerangan tersebut, sebagai salah satu bahan yang dapat dipakai dalam pertimbangan putusan pengadilan. Kalau demikian, akan banyak sekali manfaat dari kehadiran akuntan kehakiman dalam pengadilan. Melihat manfaatnya, dimana semua pihak yang berperkara tidak diperlakukan berat sebelah, maka akuntan kehakiman akan mengalami masa cerah dalam jangka waktu yang lama dan panjang.

\section{REKOMENDASI.}

Melihat kedepan, bahwa kuantitas "White Collar Crime" akan meningkat terus, yang nantinya akan meningkatkan kegiatan pengadilan, adalah tepat waktunya bila mulai dari sekarang pemanfaatan akuntan kehakiman dalam peradilan pidana digalakan pemakaiannya.

Dengan demikian kebutuhan akan akuntan kehakiman harus terus dipersiapkan peningkatan jumlahnya dengan berbagai daya tarik, karena kemungkinan akan lebih banyak akuntan yang tidak mau menjalankan profesinya sebagai akuntan kehakiman dari pada yang mau menjadi akuntan kehakiman.

\section{DAFTAR PUSTAKA}

BPKP RI, 2016, “Menggagas Audit Bervisi Kerakyatan” ISSN Jurnal Berwawasan Pengawasan - Jakarta.

Bawazir Fuad, 2015, "Visi Keuangan Negara yang Akuntable” Research eksternal Jakarta.

Brotohadihardjo R. Santoso, 2016 "Tax Law Of Science Accounting Benefit" - Eresko Bandung.

Majalah Ternama, 2016, “Peradilan MA Warta Pengawasan” - Jakarta 